\title{
Psycholinguistic Content of the Emotional Concept of «Fear» in the Contemporary English Language Picture of World
}

\section{Психолінгвістичний зміст емоційного концепту «страх» у сучасній англійській мовній картині світу}

\author{
Nataliia Mykhalchuk \\ Dr. in Psychology, \\ Professor
}

\author{
Наталія Михальчук \\ доктор психологічних наук, \\ професор
}

E-mail: natasha1273@ukr.net https://orcid.org/0000-0003-0492-9450

Researcher ID: A-9440-2019 scopus.com

Rivne State University of the Humanities, Rivne, Ukraine 12, Stepan Bandera Str., Rivne, 33000

\section{Iryna Koval}

Ph.D. in Psychology, Assistant Professor
Рівненський державний гуланітарний університет, м. Рівне, Украӥна вул. Степана Бандери, 12, м. Рівне, Україна, 33000

\section{Ірина Коваль}

кандидат психологічних наук, доцент

E-mail:iryna-koval@i.ua

https://orcid.org/0000-0002-2048-0000

Researcher ID: B-2173-2019

Khmelnytskyi National

University, Khmelnytskyi, Ukraine

11, Instytutska str., Khmelnytskyi, Ukraine, 29016
Хлельницький національний університет, л. Хлельницький, Україна вул. Інститутська, 11, м. Хмельницький, 29016 
Original manuscript received March 11, 2019

Revised manuscript accepted March 31, 2019

The author's contribution: N. Mykhalchuk $-50 \%$, I. Koval $-50 \%$. Авторський внесок: Н. Михальчук $-50 \%$, І. Коваль $-50 \%$.

\section{ABSTRACT}

In this article it is shown that in contemporary English language model of the world, the emotional concept of "fear" is one of the most commonly used by its self-identification. Fear is a universal base emotion that reflects the instinct of self-preservation and plays a leading role in providing human life. It is proved that the concept is a complex multilayer formation, the central part of which is the core. The core of the emotional-conceptual sphere is the mental representations of knowledge of the person about their own emotions as the facts of manifestation of the activity of the human emotional sphere. Its peripheral zone also includes information about all spheres of human existence that in one way or another predetermine its functioning or are interpreted through the prism of its existence. This fact testifies to the imposition of the emotional conceptual sphere on other parts of the conceptual picture of the world of the person, and, consequently, on its determinant role in the consciousness of the individual: all concepts are "emotional» from the point of view that nothing can be comprehended (conceptualized and categorized) without direct or indirect intervention in the cognition of the emotional sphere of consciousness. So, emotions are the foundation that seems to "cling" to the conceptual picture of the world of representatives of any linguistic community.

The analysis of vocabulary definitions of fear allowed us to distinguish the following main core features of the emotional concept of fear in the English language: fear is an unpleasant, painful emotion or feeling caused by the nearness or the possibility of impending danger to oneself or others who are important accompanied by a desire to avoid or to escape it.

It is determined that in the semantics of the analyzed token, there is a generic semantic "emotion" or "feeling» that points to the corresponding denotative sphere of human consciousness, represented by the superordinate (the highest level of generalization) category of emotion. All other species of this lexical unit serve to specify the meaning of tokens. Among the species the main components are the following: the lexical unit "painful» that interacts with the semantic meaning "negative» (unpleasant), "danger / threat», "desire to avoid or to escape it» - the desire to avoid or avoid the threat, "the 
nature of the impending danger» - inevitable: real / close, "the possibility of impending danger» - possible / inevitable, "oneself or somebody who is important" - the individual / people close to him.

Consequently, in contemporary English categorically different aspects of lexical unit of fear are fixed by derivative word-building units, which explicate: the state of the person; features of the character of the person; negative evaluation of the object of the threat; manner of the behavior.

Key words: psycholinguistic content of emotional concept "fear», contemporary English language picture of world, emotion-conceptual sphere, cognition of emotional sphere of consciousness, self-identification of usage.

\section{Вступ}

Сучасна психолінгвістика все частіше звертається до вивчення мовної репрезентації внутрішнього світу людини, зокрема їі емоційної сфери. Людина $є$ не тільки мислячою, але й досить емоційною істотою. Саме тому емоційність не може не залишити відбиток у мові, адже емоційні стани, зумовлюючи когнітивні процеси людини, безпосередньо втручаються до сфери їі номінативно-комунікативної діяльності.

До сфрери психолінгвістики потрапляють питання про те, яким чином здійснюється зв'язок мови зі світом, як мовні вирази, одиниці, категорії пов’язані зі сприйняттям оточення, як вони відображають його пізнання, як структури мовного знання репрезентуються у свідомості та беруть участь у обробці та передачі інформації. Аналіз мови стає невіддільним від розкриття закономірностей розумових процесів, структуризації та класифікації властивостей i функцій речей, образи яких перехоплюються, зупиняються, фіксуються вербальними формами.

У парадигмі психолінгвістичного підходу формується активне розуміння того, що саме лова забезпечує найкращий доступ до внутрішнього світу людини, до структур їі досвіду, які не спостерігаються безпосередньо. Наші уявлення про навколишню дійсність об’єктивуються у мові та створюють базис для аналізу тих процесів, що мають міс- 
це у людській свідомості та мисленні. Отже, дослідження мовних одиниць ставить за мету аналіз тих ментальних репрезентацій знання, які корелюють із ними на рівні свідомості.

Поряд із когнітивістикою одним з аспектів нової парадигми постає дискурсивність. Сутність цього принципу полягає в тому, що встановлюється розуміння мови як феномену, що слугує передачі знання від однієї людини до іншої, від одного покоління до іншого. Отже, для аналізу й опису мовних явищ ураховується виконання мовою когнітивної та комунікативної функцій і ставиться мета їх вивчення у постійній взаємодії й узгодженні між собою.

Зазначений підхід також дає змогу зрозуміти, що саме від знання про мовну систему (мовне знання) та знання про світ (енциклопедичні знання) залежить успішність комунікації. 3 цим пов'язана активізація пошуків у напрямку вивчення ролі концептів у дискурсивній практиці людини. Досліджуються засоби репрезентації концептів різнорівневими одиницями мови та мовлення, їхня смислова структура, текстотворчий потенціал, особливості індивідуальної концептуальної картини світу тощо. Тому тема нашої статті є вельми актуальною.

Мета статті - проаналізувати проблему психолінгвістичного змісту емоційного концепту «страх» у сучасній англійській мовній картині світу з огляду на ментальні репрезентації знання, що корелюють на рівні свідомості особистості.

\section{Завдання статті}

1. Окреслити концептосферу емоцій, або емоціо-концептосферу, як своєрідне світобачення, спроектоване емоційною сферою свідомості індивіда.

2. Виокремити основні змістові ознаки ядра емоційного концепту страх в англійській мові, окреслити їх психолінгвістичні характеристики. 


\section{Методи дослідження}

У роботі використано такі методи: метод контекстуального аналізу для виявлення основних функціональних характеристик досліджуваних комунікативних одиниць, для опису парадигмальної організації вербальних засобів вираження концепту страх у сучасній англійській мові, що сприяє збагаченню та подальшому розвитку теорії лінгвістичного моделювання у філологічних дослідженнях; метод безпосереднього спостереження за функціонуванням висловлювань у межах мінімального дискурсивного оточення з елементами пресупозиційного аналізу, що реалізує зв'язок (стимул) - концепт - реакція; елементи статистичних методик тощо.

\section{Результати та дискусії}

Концептосфера особистості є складовою частиною національної концептуальної картини світу, що представляє певну сукупність знань певного народу про деякий аспект його матеріального та духовного життя. Емоції як найважливіші прояви внутрішнього психічного життя людей категоризуються, утворюючи на ментальному рівні свідомості емоційну концептосферу. Концептосфера емоцій, або емоціо-концептосфера, - це світобачення, спроектоване емоційною сферою свідомості індивіда. Її можна розглядати як результат семіозису - процесу означування емоційних когніцій людини у процесі засвоєння нею оточуючого світу. Емоціо-концептосфера є цілісним холістичним когнітивним утворенням високого рівня абстракції. Загальновизнаний розподіл усіх емоцій на позитивно та негативно марковані зумовлює факт того, що емоціо-концептосфера постає тією базою, на тлі якої профілюються домени позитивної та негативної тональності, у структурі яких, у свою чергу, знаходять своє вираження усі вербально втілені концептуалізації різноманітних емоцій.

Дослідженням особливостей вираження емоційного концепту «страх» за допомогою лексичних і фразеологіч- 
них одиниць переважно у порівняльному аспекті на матеріалі сучасних мов займалися Е. Е. Івашкевич і Н. О. Михальчук (Івашкевич \& Михальчук, 2018), О. С. Колесник (Колесник, 2003), А. Е. Левицький (Левицький, 2004). У дослідженнях учених установлено, що зв'язок процесів пізнання та мислення з емоційною сферою життя людини $є$ очевидним і незаперечним. Знання та емоції вербалізуються у мові та створюють базис для аналізу процесів мовлення і мислення (Onufriieva, 2016). Емоції є важливим компонентом життя людини, вони є саме тією сферою свідомості, яка за допомогою мовних засобів впливає на процес номінації та комунікації. Активна участь емоцій у перебігу індивідуальної пізнавальної діяльності зумовлює нерозривний зв'язок між емоційною сферою та мовною системою, оскільки свідомість відображає образи об'єктивної дійсності у сукупності з суб'єктивно-емоційним ставленням реципієнта до них (Onufriieva, 2017). Людина є емоційним індивідом, здатним аналізувати й давати оцінку явищам об'єктивної дійсності, лише мова надає змогу дослідникам вивчати внутрішній світ людини, який не спостерігається безпосередньо.

Емоції виражаються вербальними та невербальними засобами. Невербальна репрезентація емоцій може бути досить яскравою, але їх майже неможливо точно передати без використання вербальних засобів. Отже, в експлікації емоційної сфери життя людини значну роль відіграють саме мовні та мовленнєві засоби репрезентації емоцій.

У сучасній англійській мовній картині світу емоційний концепт «страх" є одним із найпоширеніших за самоідентифікацією вживання. Страх є універсальною базовою емоцією, що відображає інстинкт самозбереження й відіграє провідну роль у забезпеченні життєдіяльності людини.

Як зазначає Ю. М. Лотман (Лотман, 2001), страх є однією з фундаментальних емоцій, що виконує захисну функцію та супроводжується певними змінами діяльності вищої нервової системи, а саме: зміною частоти пульсу та дихан- 
ня, показників артеріального тиску, роботи шлунку. Однак слід зауважити, що почуття страху стимулює здатність реагувати на несприятливі чинники об’єктивної дійсності. Перебуваючи у найвищій точці емоційного збудження, людина шукає шляхи розв'язання проблеми, оскільки страх специфічно викривляє дійсність, накладаючи відбиток на характер їі сприйняття й інтерпретації. У несприятливій ситуації людина прагне якнайшвидше позбавитись від стану безпорадності, наляканості, мінімізувати дію загрожуючого чинника. Ми можемо зробити висновок, що уявлення щодо емоції «страх» локалізуються у негативній асоціативно-образній зоні мовної картини світу.

Проте слід зазначити, що страх являє собою силу, здатну як руйнувати особистість зсередини, залишаючи її безпорадною перед обставинами, так і мобілізувати внутрішні сили людини, допомагаючи тим самим уникнути небезпеки, врятуватися, оскільки є надзвичайно сильним мотиваційним чинником для моделювання поведінки особистості. Страх можна справедливо віднести до провідних чинників, що сприяли розвитку цивілізації. Саме відчуття реальної або уявної загрози стимулювало людство об'єднуватися у племена, громади (з яких згодом утворювались міста і держави), оскільки разом було набагато легше протистояти нападам звірів, інших племен і навіть стихійним лихам. Однією з підвалин релігійних вірувань є страх бути покараним вищими силами або зазнати страждань після смерті, яка у багатьох релігіях є межею між земним існуванням і вічним життям на небесах. Ця теза дає можливість розглядати досліджувану емоцію як чинник мотивації моральності поведінки сучасної людини.

Концепт є складним багатошаровим утворенням, центральною частиною якого є ядро. Ядро емоціо-концептосфери складають ментальні репрезентації знання щодо власне емоцій як факти прояву діяльності емоційної сфери людини. До її периферійної зони включається також інформація про усі сфери буття людини, які так чи інакше 
зумовлюють її функціонування або осмислюються через призму її існування. Цей факт свідчить про накладання емоційної концептосфери на інші ділянки концептуальної картини світу індивіда, а, отже, щодо її детермінуючої ролі у свідомості особистості: усі концепти є «емоційними» з точки зору того, що нічого не може бути осмислено (проконцептуалізовано та прокатегоризовано) без прямого чи непрямого втручання у когніцію емоційної сфери свідомості. Тож, емоції є тим підгрунтям, що ніби «скріплює» концептуальну картину світу представників будь-якої мовної спільноти.

У працях Л. А. Онуфрієвої (Онуфрієва, 2014) зазначено, що емоційна концептосфера є динамічною лабільною семіотичною системою, історично-соціальним утворенням, розвиток якого зумовлений як екстралінгвістичними, так і власне лінгвістичними чинниками. Лінгвістичними чинниками, що визначають розвиток емоціо-концептосфери у діахронії культури, є асиметрія мовного знака, розширення регістрів людського спілкування, соціальна, стилістична диференціація мови. Основними екстралінгвістичними чинниками, що визначають формування і трансформацію емоціо-концептосфери, є ускладнення практичної діяльності людини, поява теоретичного знання як способу опанування людиною світу, соціалізація особистості, моральна орієнтація суспільних інститутів тощо.

Переважна частина емоціо-концептосфери є вербалізованою. Вона знаково оформлюється досить різноплановими мовними засобами, переважно вторинної номінації метафорою та метонімією: усі абстрактні концепти, у тому числі й емоційні, є метафоричними за своєю природою. Широке використання засобів вторинного означування емоцій зумовлено великою розповсюдженістю та продуктивністю таких типів номінації у мові на її сучасному етапі розвитку внаслідок, з одного боку, бідності прямих позначень психічного світу людини, а з іншого боку - архетиповості когніцій людини (Лосєв, 1982). 
Непрямі номінації емоцій є процесом і результатом оцінного переосмислення вже існуючих мовних реалій. В основі сучасного позначення емоцій покладено переноси найменувань реальних фрагментів світу (фізіологічні реакції організму людини, ïï фізичні дії, явища природи, міфологічні образи тощо) на психічну діяльність людини.

Організаційно емоціо-концептосфера являє собою сукупність ієрархічно упорядкованої парадигми, вербалізованої за допомогою лексичних і фразеологічних засобів емоційних концептів - «квантів» - структурованого знання щодо емоційного життя індивіда, які знаходяться один з одним у складних структурно-семантичних і функціональних відношеннях. Тому для дослідження природи емоціо-концептосфери надзвичайно важливо зрозуміти сутність емоційного концепту, описати і відобразити його складові, проаналізувати ті мовні засоби, якими вони репрезентуються. Такий опис потребує врахування існуючих у соціокультурному житті спільноти психологічних, соціологічних і семіотичних чинників, що у сукупності утворюють загальнокультурний чинник, який детермінує формування та функціонування концептів як когнітивнокультурних явищ.

Одним із ядерних концептів у структурі емоціо-концептосфери є емоційний концепт страх, що акумулює знання про базову емоцію, без якої не можливе саме існування людини. Емоція страх є одним із найважливіших компонентів емоційної концептосфери людини, що зумовлює процес пізнання та орієнтації людини у світі й характеризується біологічними, психологічними та соціокультурними вимірами. Страх є фундаментальною властивістю людської істоти, природною універсальною базовою емоцією, що відображає інстинкт самозбереження і відіграє провідну роль у забезпеченні життєдіяльності людини. Функціональне призначення страху полягає у тому, що він виявляється у вигляді афективно загостреного сприйняття загрози для життя, благополуччя чи самопочуття людини й активної 
чи пасивної реакції на несприятливі чинники навколишнього середовища. Погляд на світ крізь призму небезпеки призводить до специфічного викривлення дійсності, що безпосередньо позначається на: характері її сприйняття індивідом, правильності інтерпретації ним подій, вдалому виборі шляхів подолання труднощів тощо. При цьому, крім прототипового «перспективного» прочитування страху як реакції на загрозливу майбутню подію, він може поставати як «ретроспективна» емоція, що виникає у разі розумового відтворення вже пережитої у минулому небезпеки.

Отже, першопричиною появи страху є фізичне чи ментальне сприйняття певного стану речей, яке категоризується свідомістю як небезпечна ситуація, що не відповідає потребі людини у почутті безпеки. Зазначена оцінка зумовлена тим, що виникає неузгодженість між змістовим компонентом настановлення та образом реальної ситуації - когнітивний дисонанс, який переживається як стан дискомфорту. Останній неминуче призводить до пошуку можливостей повернення почуття безпеки та спокою.

Стан страху безпосередньо виявляється у мимовільних нейрофізіологічних і нейромоторних реакціях індивіда. До них відносяться, наприклад, такі симптоми, як неможливість сконцентруватися, зниження тонусу мускулатури, збільшення частоти серцебиття, що відображає неспокій, дискомфорт, зміни у міміці та пантоміміці, мимовільні мовленнєві вигуки тощо. Ці симптоми є підставою для класифікації емоції як неприємної, такої, що приносить невдоволення, у більшості випадків дезорганізує діяльність індивіда, i, відповідно, оцінюється ним як негативна.

Після первинної інтуїтивної оцінки обов'язково з'являється більш усвідомлена інтелектуальна оцінка як самої небезпеки, так і свого психофізіологічного та фізичного стану. Оцінка тягне за собою появу осмисленого бажання припинення впливу несприятливого чинника, яке здійснюється через глибший аналіз можливих шляхів виходу із ситуації та вироблення плану дій. Кристалізація замислу 
детермінується тим, як суб’єкт обмірковує план і приймає початкове та кінцеве рішення відносно тих кроків, що призведуть до бажаного результату. Сама емоція й оцінка сприяють формуванню інтенції, експлікують початок і кінець вольового акту .

На виході з ситуації відбуваються повністю чи частково усвідомлені й контрольовані дії та мовні реакції суб’єкта на чинник, що викликає страх: адаптація до навколишніх умов чи боротьба, або, навпаки, повне підкорення цьому емоційному переживанню з наступними негативними або позитивними для індивіда наслідками. При цьому людина, як правило, орієнтується на минуле знання.

Поява значної кількості різноспрямованих досліджень елементів лексико-семантичного поля страх пояснюється також високою біологічною та соціальною значущістю емоції страх, наявністю їі численних різновидів. Семантика таких одиниць розглядається як результат категоризації мисленням комунікантів відповідних емоційних проявів свідомості та фіксація категоризації зазначеної ділянки досвіду у вигляді емоційного концепту страх.

Дослідження лексем англійської мови, які репрезентують емоцію «страх», показало, що спільне поняття для елементів лексико-семантичного поля страх у найбільш «чистому» вигляді представлено в архілексемі fear. Вона є домінантою й ідентифікатором поля, оскільки поняття, нею зафіксоване, тією чи іншою мірою представлено у дефініціях усіх представників поля. Назва емоції - знакове утворення, що фіксує собою концепт не тільки як когнітивну структуру, але і як «згусток культури». Вивчення знаку емоції як когнітивно-культурного феномену є лінгвосеміотичним способом декодування самого концепту, визначення та побудови його концептуальної структури.

Визначення семантики fear як базової номінанти емоції страх $\mathrm{\epsilon}$, на наш погляд, досить проблематичним унаслідок абстрактності відповідного денотату. Крім того, незва- 
жаючи на потяг лексикографів до уніфікації й регулярності опису одиниць лексичного поля, різні лексикографічні рішення відрізняються відмінностями у категоріальному статусі відповідної інформації щодо оточуючого світу й етапів її усвідомлення як окремої чи нової категорії. Саме тому для аналізу дефініцій ми застосовуємо синтезуючий підхід, який полягає у формулюванні єдиного загального значення лексичної одиниці на основі визначень, наведених у декількох словникових джерелах. Такий підхід дає змогу більш повно і точно представити зміст психічних понять, більшість із яких є онтологічно близькими одне до одного. Отримана симбіозна дефініція є розширеним варіантом тлумачення лексеми, що характеризується семантичною достатністю й інформаційною суверенністю.

Аналіз словникових дефініцій лексеми fear дав підстави виокремити такі основні змістові ознаки ядра емоційного концепту страх в англійській мові: fear is an unpleasant, painful emotion or feeling caused by the nearness or possibility of impending danger to oneself or others who are important accompanied by a desire to avoid or to escape it.

У семантиці аналізованої лексеми міститься загальна родова сема «емоція», або «почуття» (emotion, or feeling), що вказує на відповідну денотативну сферу свідомості людини, репрезентовану суперординатною (найвищого рівня узагальнення) категорією елоція. Усі інші видові семи слугують для конкретизації значення лексеми. Серед видових компонентів виокремлюються: сема "характер емоціï» (painful), яка взаємодіє із семами «негативна оцінка» (unpleasant - неприємна), «небезпека / загроза» (danger небезпека, загроза), «симптом емоції» (desire to avoid or to escape it - бажання уникнути чи ухилитися від загрози), «характер небезпеки / загрози» (nearness of impending danger - неминуча: реальна / близька; possibility of impending danger - можлива / неминуча), «об'єкт загрози» (oneself or somebody who is important - індивід / близькі йому люди). 
Внутрішня форма емоційного концепту страх, яка виявляється внаслідок етимологічного аналізу його ключового слова, за лексикографічними даними, зазнала суттевих змін. Етимологічною основою лексеми fear є германський корінь *fer, що означало «небезпеку, шкоду», fer: sudden calamity, danger "раптове лихо, небезпека; власне страх», яке відповідає far: ambush «пастка»; far «икода, розпач, облан»; far «зло, шкода, нещастя»; fara «небезпека, переляк». Порівняння сучасної дефініції слова fear і поданих давніх його відповідників свідчить про те, що раніше у ядерній зоні емоційного концепту страх локалізувалася інформація про небезпеку, що є причиною виникнення страху, тоді як зараз базовими є знання про власне ознаки емоційного стану індивіда.

На підтвердження такого висновку вважаємо за доцільне навести думку А. Е. Левицького (Левицький, 2004), який стверджує, що сучасне значення слова fear пов'язано 3 грецьким peira (*peria) «досвіة» і латинським experiri «пробувати, випробувати». Як бачимо, в структурі емоційного концепту страх відбулися акцентні зрушення, що спричинили перекомпонування ядерно-периферійних елементів.

Отже, у сучасній англійській мові категоріально різні аспекти одиниці fear фіксуються похідними словотвірними одиницями, які експлікують:

- стан індивіда: синонімічні прикметники fearful i fearsome - full of fear; frightened that something might hapреп (повний страху; наляканий тил, що щось може траnитись) і лексема fearable - to be frightened (наляканий); іменникові синоніми fearsomeness i fearfulness - quality or state of being affected with fear (стан наляканості);

- риси характеру індивіда: прикметник fearless - not afraid of anything (безстрашний, безбоязний) та іменник fearlessness (безстрашність, безбоязність);

- негативну оцінність об'скта загрози: fearful - extremely bad; very frightening (надзвичайно поганий; дуже 
лякаючий); fearsome - very frightening (дуже лякаючий); fearable - giving cause for fear і субстантивні синоніми fearfulness, fearsomeness - quality of being fearsome (лnотороuність, жахливість);

- манеру поведінки: fearfully - in a way that shows you are afraid (діяти (вести) певнил чинол, виявляючи свій cmpax) або fearfully, fearsomely - in a fearsome manner (загрозливо, шляхол навіювання страху) (негативна маркованість) i fearlessly - in a way that shows you are not afraid (діяти, (вести) певнил чинол, не виявляючи страху) (позитивна маркованість).

Семантична структура одиниць на позначення емоцій містить також аксіологічні семи, внаслідок оцінювання афектованою особою певного фрагмента оточуючого світу та самої ролі конкретної емоції у її життєдіяльності, зокрема у конкретному просторово-часовому відрізку. В семантиці лексем номінативного простору емоційного концепту страх, окрім денотативних ознак, виокремлюються семи оцінного характеру, що свідчить про наявність конотативного аспекту значення. Під конотацією розуміємо семантичну сутність, яка узуально або оказіонально входить до значення мовної одиниці та виражає оцінне і стилістично марковане ставлення суб'єкта мовлення до дійсності у випадку їі позначення у висловленні, яке отримує на основі цього експресивний ефект. Конотація у формі негативної оцінки, що фіксується диференційними семами unpleasant i painful (emotion / feeling) лексеми fear, супроводжуючи велику кількість одиниць лексико-семантичного поля «страх», має нечітко експлікований характер (за винятком лексем дальньої та маргінальної периферії), тому вказана парадигма відноситься нами до умовно нейтральної лексики. У словникових тлумаченнях лексеми fear та номінацій усіх інших форм емоції не фіксується її позитивна роль як сигналу небезпеки та з огляду на потребу їі усунення чи уникнення. Тому позитивна оцінна сема, що відображає 
надзвичайну значущість страху в житті людини, знаходиться на периферії емоційного концепту страх.

\section{Висновки}

Отже, зазначені родова та диференційні ознаки, притаманні лексемі fear, включаючи оцінні компоненти, є прототиповими для осмислення емоції страх. Тому зазначена лексема позначає центральний член концептуальносемантичної структури емоційного концепту страх і, відповідно, є центром лексико-семантичного поля страх, яке групує лексичні мовні засоби представлення відповідного концепту в сучасній англійській мові.

Під час установлення та опису організаційних зв’язків, якими характеризуються емотиви номінативного простору емоційного концепту страх, ми дотримуємося думки про те, що базисні номінанти емоцій мають лінгвістичний статус гіперонімів, тоді як інші номінанти емоцій однієї онтології постають у якості гіпонімів, виявляючи таким чином відносини синонімії між одиницями одного чи сусідніх рівнів ієрархії. Така позиція грунтується на тому, що на відміну від об’єктів навколишнього світу, які, завдяки своїй конкретності, вписуються у природну таксономію олюдненого свідомістю буття, емоційні стани, що не мають дискретної природи, характеризуються мінливістю своїх ознак, переходом у інші стани, тобто, складністю свого усвідомлення та іменування. Тому абстрактність емоцій, зафіксована семантикою емотивних номінантів, дає підстави говорити про інші способи розміщення таких номінацій у лексичній мовній системі.

Отже, враховуючи те, що архілексемою поля постає дифузна одиниця з багатьма значеннями, яка вказує на денотативну належність аналізованих слів, констатуємо виконання лексемою fear ролі гіпероніма щодо всіх інших синонімічних їй та один одному номінантів стану страху. Ідеться про концептуальні структури значень синонімів, що позначають форми прототипової емоції страх. Концен- 
труючись навколо страху, вони відрізняються інтенсивністю переживань і власне якісними ознаками. Зазначені синоніми високого рівня абстракції, вказуючи на досить складний і специфічний об'єкт дослідження, виконують роль еквонімів - одиниць одного класу, які включають смисловий зміст гіпероніма та протиставляються один одному відповідними диференційними семами.

\section{Література}

Колесник О. С. Мовні засоби відображення міфологічної картини світу: лінгво-когнітивний аспект (на матеріалі давньоанглійського епосу та сучасних британських художніх творів жанру фентезі): дис. ... канд. філол. наук: 10.02.04. Київ, 2003. 300 с.

Левицький А. Е. Основи функціональної лінгвістики. Ніжин : Редакційно-видавничий відділ НДПУ, 2004. $124 \mathrm{c.}$

Лосев А. Ф. Знак. Символ. Миф. Москва : Изд-во Моск. ун-та, 1982.480 с. Лотман Ю. М. Семиосфера. Санкт-Петербург : «Искусство-СПб», 2001. $704 \mathrm{c}$.

Ivashkevych E. E., Mykhalchuk N. O. Art translation and the category of expressivness in this estetic paradigm. Актуальні проблеми філологї та методики викладання гуманітарних дисциплін: Наук. записки РДГУ. Рівне : РДГУ, 2018. С. 153-157.

Onufriieva L. A. Professional self-appraisal at the professional formation of future socionomic specialists' personality. Проблеми сучасної психології: зб. наук. пращь Кам'янець-Подільського національного університету імені Івана Огієнка, Інституту психології імені Г. С. Костюка НАПН Украӥни / За наук. ред. С. Д. Максименка, Л. А. Онуфрієвої. Кам'янець-Подільський : Аксіома, 2016. Вип. 26. С. $456-467$.

Onufriieva, L. A. (2016). Emotional intelligence in the future socionomic specialists' professional psychological training. Science and Education a New Dimension. Pedagogy and Psychology, IV (47), Issue 101, 34-37. Budapest.

Onufriieva, L. A. (2017). The Psychology of Professional Realization of a Future Specialist's Personality: Theoretical and Methodological Aspect. Monograph. Rzeszów : BonusLiber. $194 \mathrm{~s}$.

\section{References}

Kolesnyk, O. S. (2003). Movni zasoby vidobrazhennia mifolohichnoi kartyny svitu: linhvo-kohnityvnyi aspekt (na materiali davnioanhliiskoho eposu ta suchasnykh brytanskykh khudozhnikh tvoriv zhanru 
fentezi) [Linguistic means of displaying the mythological picture of the world: lingvo-cognitive aspect (based on the material of the Old English epic and contemporary British novels, the genre of fantasy)]. Extended abstract of candidate's thesis. Kyiv [in Ukrainian].

Levytskyi, A. E. (2004). Osnovy funktsionalnoi linhvistyky [Fundamentals of Functional Linguistics ]. Nizhyn : Redaktsiino-vydavnychyi viddil NDPU [in Ukrainian].

Losev, A. F. (1982). Znak. Simvol. Mif [Sign. Symbol. Myth]. Moskva : Izd-vo Mosk. un-ta [in Russian].

Lotman, Ju. M. (2001). Semiosfera [Semio-sphere]. Sankt-Peterburg : «Iskusstvo-SPb» [in Russian].

Ivashkevych, E. E., \& Mykhalchuk, N. O. (2018). Art translation and the category of expressivness in this aesthetic paradigm. Aktualni problemy filolohii ta metodyky vykladannia humanitarnykh dystsyplin: Nauk. zapysky RDHU - Actual problems of philology and Methods of teaching of humanities: Scientific Notes of RSUH, 153-157. Rivne : RDHU [in Ukrainian].

Onufriieva, L. A. (2014). Professional self-appraisal at the professional formation of future socionomic specialists' personality. S. D. Maksymenko, L. A. Onufriieva (Eds.). Problemy suchasnoi psykholohii: $z b$. nauk. prats Kamianets-Podilskoho natsionalnoho universytetu imeni Ivana Ohiienka, Instytutu psykholohii imeni H. S. Kostiuka NAPN Ukrainy - Problems of Modern Psychology. Collection of research papers of Kamianets-Podilskyi National Ivan Ohiienko University, G. S. Kostiuk Institute of Psychology of the National Academy of Educational Sciences of Ukraine, 26, 456-467. Kamianets-Podilskyi : Aksioma [in Ukrainian].

Onufriieva, L. A. (2016). Emotional intelligence in the future socionomic specialists' professional psychological training. Science and Education a New Dimension. Pedagogy and Psychology, IV (47), Issue 101, 34-37. Budapest.

Onufriieva, L. A. (2017). The Psychology of Professional Realization of a Future Specialist's Personality: Theoretical and Methodological Aspect. Rzeszów : BonusLiber.

\section{Михальчук Наталія, Коваль Ірина. Психолінгвістичний зміст емоцій- ного концепту "страх» у сучасній англійській мовній картині світу}

\section{АНОТАЦІЯ}

У статmі зазначено, що у сучасній англійській мовній картині світу емоційний концепт "страх» $\epsilon$ одним із найпоширеніших за самоідентифікацією вживання. Страх є універсальною базовою емоцією, що відображає інстинкт самозбереження й відіграє провідну роль у за- 
безпеченні життєдіяльності людини. Обгрунтовано, що концепт $\epsilon$ складним багатошаровим утворенням, чентральною частиною якого $\epsilon$ ядро. Ядро емоціо-кониептосфери складають ментальні репрезентації знання щодо власне емоцій як факти прояву діяльності емоційної сфери людини. До ії периферійної зони включається також інформація про усі сорери буття людини, які так чи інакше зумовлюють ії функціонування або осмислюються через призму ії існування. Цей факт свідчить про накладання емоційної концептосфери на інші ділянки концептуальної картини світу індивіда, a, отже, щодо ії детермінуючої ролі у свідомості особистості: усі концепти є «емоційними» з точки зору того, що нічого не може бути осмислено (проконцептуалізовано та прокатегоризовано) без прямого чи непрямого втручання у когніцію емоційної сфери свідомості. Тож, емоції є тим підгрунтям, яке ніби «скріплює» концептуальну картину світу представників будь-якої мовної спільноти.

Аналіз словникових дефініцій лексеми fear дав змогу виокремити такі основні змістові ознаки ядра емоційного концепту страх в англійській мові: fear is an unpleasant, painful emotion or feeling caused by the nearness or possibility of impending danger to oneself or others who are important accompanied by a desire to avoid or to escape it.

Зазначено, що у семантиці аналізованої лексеми міститься загальна родова сема "емоція», або "почуття» (emotion, or feeling), яка вказує на відповідну денотативну сферу свідомості людини, репрезентовану суперординатною (найвищого рівня узагальнення) категорією "емоція». Усі інші видові семи слугують для конкретизації значення лексеми. Серед видових компонентів виокремлюються: сема «характер емоції» (painful), яка взаємодіє з семами «негативна оцінка» (unpleasant - неприємна), «небезпека / загроза» (danger - небезпека, загроза), "симптом емоції» (desire to avoid or to escape it - бажання уникнути чи ухилитися від загрози), “характер небезпеки / загрози» (nearness of impending danger - неминуча: реальна / близька; possibility of impending danger - можлива / неминуча), "об'єкт загрози» (oneself or somebody who is important - індивід / близькі йому люди).

Визначено, що у сучасній англійській мові категоріально різні аспекти одиниці fеar фіксуються похідними словотвірними одиницями, що експлікують: стан індивіда; риси характеру індивіда; негативну оцінність об'єкта загрози; манеру поведінки тощо.

Ключові слова: психолінгвістичний зміст емоційного концепту "страх», сучасна англійська мовна картина світу, емоціо-концептос- 
фрера, когніція емоційної сфери свідомості, самоідентифікація вживання.

Михальчук Наталия, Коваль Ирина. Психолингвистическое содержание эмоционального концепта "страх» в современной английской языковой картине мира

\section{АННОТАЦИЯ}

В статье указано, что в современной английской языковой картине мира эмоциональный концепт "страх» является одним из самых распространенных по самоидентификации употребления. Страх является универсальной базовой эмоцией, отображающей инстинкт самосохранения, и играет ведущую роль в обеспечении жизнедеятельности человека. Обосновано, что концепт является сложным многоуровневым образованием, центральной частью которого является ядро. Ядро эмоцио-кониептосферы составляют ментальные репрезентации знания собственных эмоций и факты проявления деятельности эмоциональной сферы человека. В её периферийную зону входит также информация о всех сферах бытия человека, которые так или иначе обусловливают её функционирование или осмысливаются через призму её существования. Этот факт свидетельствует о наложении эмоциональной концептосферы на другие участки концептуальной картины мира индивида, что, следовательно, подчеркивает её доминирующую роль в сознании личности: все концепты являются «эмоциональными» с точки зрения того, что ничего не может быть осмыслено (проконцептуализировано и прокатегоризировано) без прямого или косвенного вмешательства в когниции эмоциональной сферы сознания. Поэтому эмоции являются тем фундаментом, который как бы "скрепляет» концептуальную картину мира представителей любой языковой общности.

Анализ словарной дефиниции лексемы fear позволил выделить следующие основные содержательные признаки ядра эмоционального концепта страх в английском языке: fear is an unpleasant, painful emotion or feeling caused by the nearness or possibility of impending danger to oneself or others who are important accompanied by a desire to avoid or to escape it.

Отмечено, что в семантике анализируемой лексемы содержится общая родовая сема "эмоция», или «чувство» (emotion, or feeling), которая указывает на соответствующую денотативную сферу сознания человека, представленную суперординатной (наиболее высокого уров- 
ня обобщения) категорией “эмоция». Все остальные видовые семы служат для конкретизации значения лексемы. Среди видовых компонентов выделяются: сема «характер эмоции» (painful), которая взаимодействует с семами "негативная оценка» (unpleasant - неприятная), «опасность / угроза» (danger - опасность, угроза), "симптом эмоции» (desire to avoid or to escape it - желание избежать или уклониться от угрозы), "характер опасности / угрозы» (nearness of impending danger неизбежная: реальная / близкая; possibility of impending danger - возможная / неизбежная), "объект угрозы» (oneself or somebody who is important - индивид / близкие ему люди).

Определено, что в современном английском языке категориально различные аспекты единицы fеar фиксируются производными словообразовательными единицами, которые эксплицируют: состояние индивида; черты характера индивида; негативную оценку объекта угрозы; манеру поведения.

Ключевые слова: психолингвистическое содержание эмоционального концепта "страх», современная английская языковая картина мира, эмоцио-концептосфера, когниция эмоциональной сферы сознания, самоидентификация употребления. 